\title{
THE IMPACT OF SHEAR WALL LOCATION ON THE SEISMIC RESPONSE OF RC FRAME BUILDINGS RESTING ON SLOPING GROUND
}

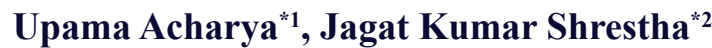

\begin{abstract}
It is observed during the past earthquakes, buildings in hilly regions have experienced high degree of damage leading to collapse though they have been designed for safety of the occupants against natural hazards. Hence, while adopting practice of multistory buildings in these hilly and seismically active areas, utmost care should be taken for making these buildings earthquake resistant. For the buildings on sloping ground, the height of columns below plinth level is not same which affects the performance of building during earthquake. Hence to improve the seismic performance of building shear walls play very important role.It is very necessary to determine the most effective location of shear walls. Shear wall arrangement must be accurate, because if not, it will cause negative effect instead. This paper is aimed at predicting the effect of positioning RC shear wall of different shape on the structural response of $\mathrm{RC}$ building resting on sloping ground. Eight models have been prepared considering earth pressure and without considering earth pressure. The displacement of building is to be determined by nonlinear static pushover analysis. For the purpose of pushover analysis and response spectrum analysis finite element-based software SAP 2000 has been utilized.
\end{abstract}

Keywords Sloping ground-RC Shear Wall-SAP2000-Response Spectrum Analysis-Pushover Analysis

\section{Introduction}

Buildings on hills are different from those in plains; they are very irregular and unsymmetrical in horizontal and vertical planes, and torsion coupled[1]. Buildings resting on sloping ground are more prone to damage than on buildings resting on flat ground even with plan irregularities[5]. Most of the hilly areas come under seismic zones; hence buildings built in such areas are highly vulnerable to earthquake. The necessary earthquake resistant capacity in such building can be achieved by providing adequate stiffness, strength and ductility and shear wall provides an optimum means of achieving the basic criteria of design[3]. The building on sloping ground is unsymmetrical about one of the principle axis and hence location of shear wall becomes crucial[6].Performance is improved by addition of shear wall and it is an ideal solution to improve the seismic performance of open ground storey building on sloping ground[7].Shear walls are specially designed structural walls included in the buildings to resist horizontal forces

Department of Civil Engineering, Pulchowk Campus, IOE, TU, Nepal

Corresponding Author

Email : jagatshrestha@ioe.edu.np 
that are induced in the plane of the wall due to wind, earthquake and other forces. They are mainly flexural members and usually provided in high-rise buildings to avoid the total collapse of the high-rise buildings under seismic forces. Shear wall has high in-plane stiffness and strength which can be used to simultaneously resist large horizontal loads and support gravity loads. Presence of shear wall considerably reduces the base shear and lateral displacement.Shear walls must provide the necessary lateral strength to resist horizontal earthquake forces. When shear walls are strong enough, they will transfer these horizontal forces to the next element in the load path below them. These other components in the load path may be other shear walls, floors, foundation walls, slabs or footings. Shear walls also provide lateral stiffness to prevent the roof or floor above from excessive sideway. When shear walls are stiff enough, they will prevent floor and roof framing members from moving off their supports. Also, buildings that are sufficiently stiff will usually suffer less nonstructural damage.

\section{Objective and Methodology}

Objectives of this study is to evaluate the impact of shear wall location of RC frame buildings resting on sloping ground conducting linear static, linear dynamic and pushover analysis. The seismic behavior of building with and without shear wall resting on plain and sloping ground is also studied. Eight models are used for study considering earth pressure and without considering earth pressure.

\section{Building Description}

Model consists of $\mathrm{G}+8$ storey $\mathrm{RC}$ building having 4 bays in both directions, each bay width is $4 \mathrm{~m}$, storey height $3 \mathrm{~m}$. The RC frame consists of beam size $300 \mathrm{~mm}$ x 400

and column size is $500 \mathrm{~mm} \times 500 \mathrm{~mm}$, shear wall thickness $200 \mathrm{~mm}$, grade of concrete M25 for beam, slab, shear wall, grade of steel Fe 500.Three of the models are analyzed considering earth pressure whereas the other three are analyzed without considering earth pressure. The slope of ground is 27 degree with horizontal. The model taken for the analysis is as shown in figure below:

\section{Analysis and Result}

Linear static method of analysis using seismic code IS 1893:2002 is carried out to corporate the design of buildings with the earthquake force. Response spectrum analysis is also performed to obtain forces, stresses and deflections. A three-dimensional model created in SAP2000 is used to carry out nonlinear static analysis analysis. Displacement controlled load is applied and the displacement is monitored upto $4 \%$ of building height. Results are saved for multiple steps. The study of RCC Building with varying position of shear wall situated in slope ground and plain ground located in Nepal (Zone V) is presented using equivalent static method and response spectrum method (IS 1893:2002) followed by pushover analysis as per ATC 40 and FEMA-356.For model M1(b), M2(b) and M3(b) i.e building situated in slope ground earth pressure have been considered. The 
seismic force was applied in X-direction and Y-direction as eqx and eqy respectively. The modeling of Building on varying location of shear wall was done and comparative analysis was performed. The results were compared based on the time period,

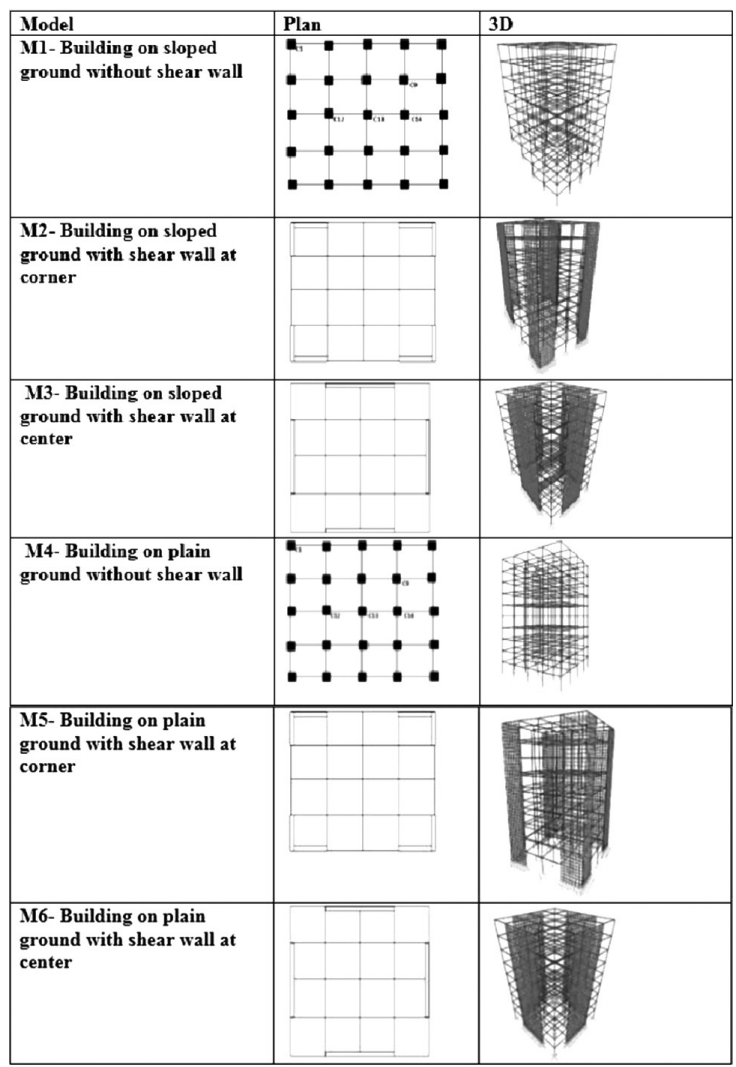

Fig 1: Plan and Elevation of models

Base Shear, Displacement, Performance Points. Important results are presented in the subsequent sections.

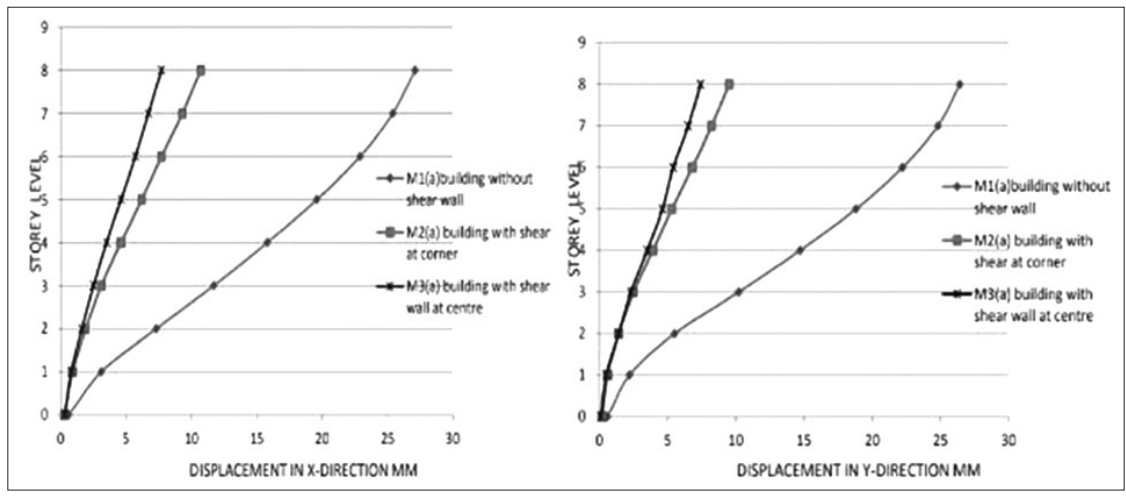

Fig 2: Lateral displacement of $M 1(a), M 2(a)$ andM3(a) in $\mathrm{mm}$ due to static analysis along $X$ and $Y$ direction 
The Impact of Shear Wall Location ...
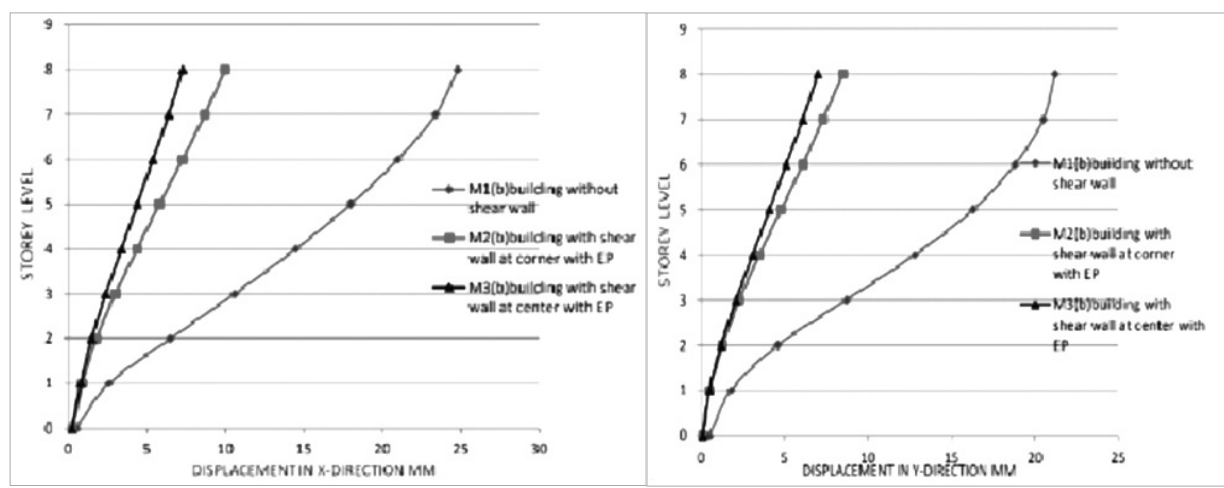

Fig 3: Lateral displacement of M1(b), M2 (b) and M3 (b) in mm due to static analysis along $X$ and $Y$ direction
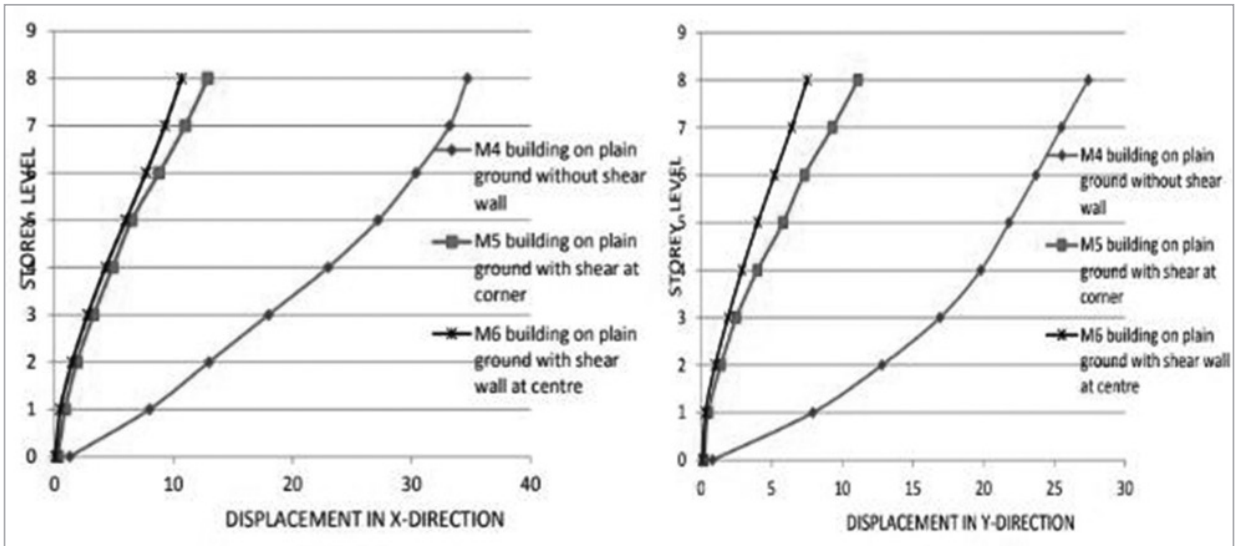

Fig 4: Lateral displacement of M4, M5 and M6 inmm due to static analysis along $X$ and $Y$ direction
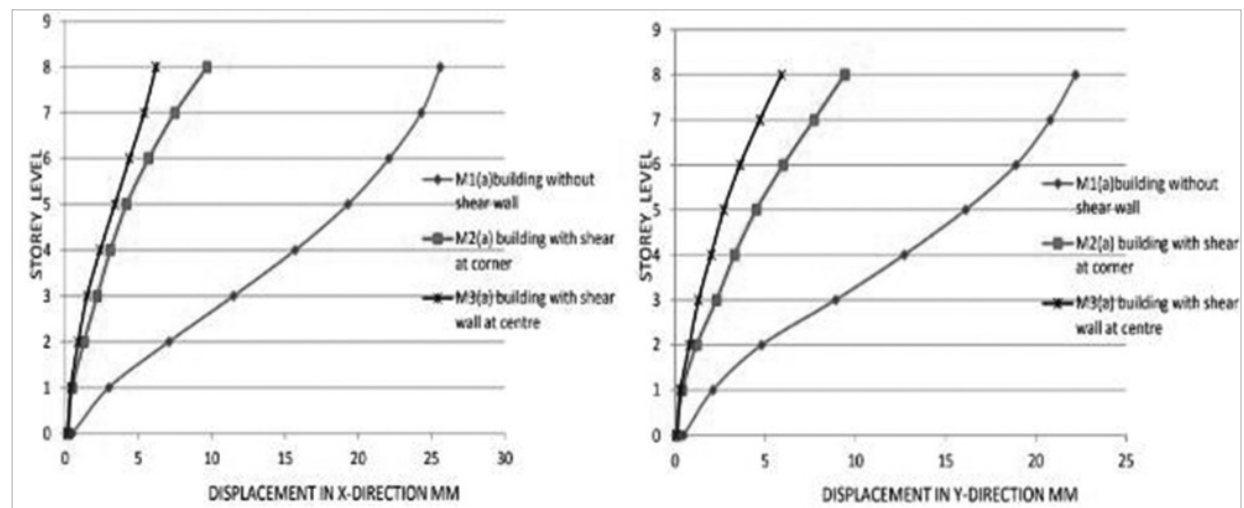

Fig 5: Lateral displacement of $M 1(a), M 2(a)$ andM3(a) in mm due to response spectrum analysis along $X$ and $Y$ direction 


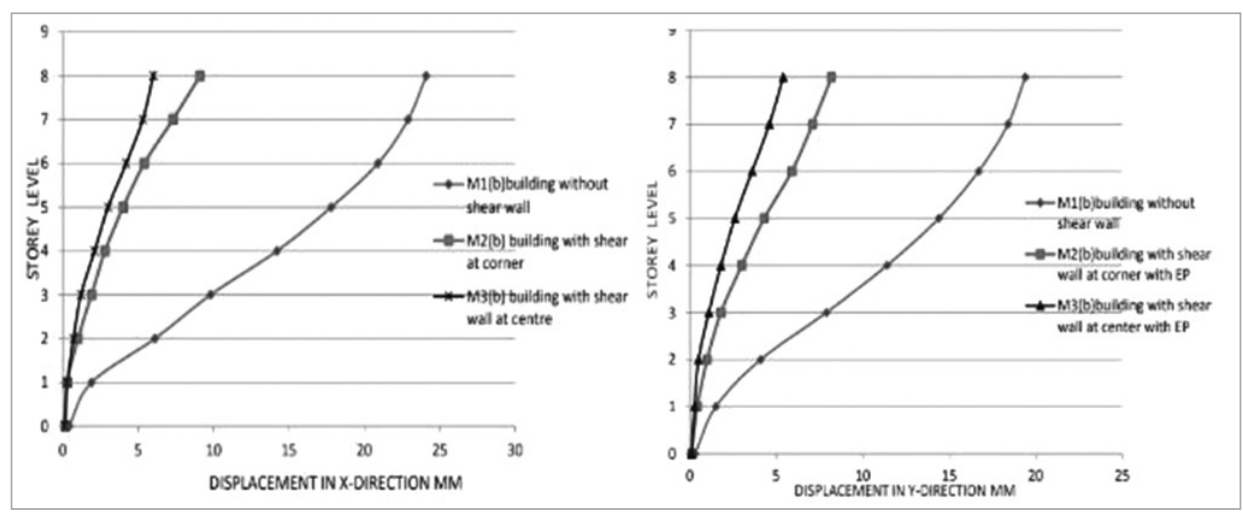

Fig 6: Lateral displacement of M1(b), M2(b) and M3(b) in mm due to response spectrum analysis along $X$ and $Y$ direction

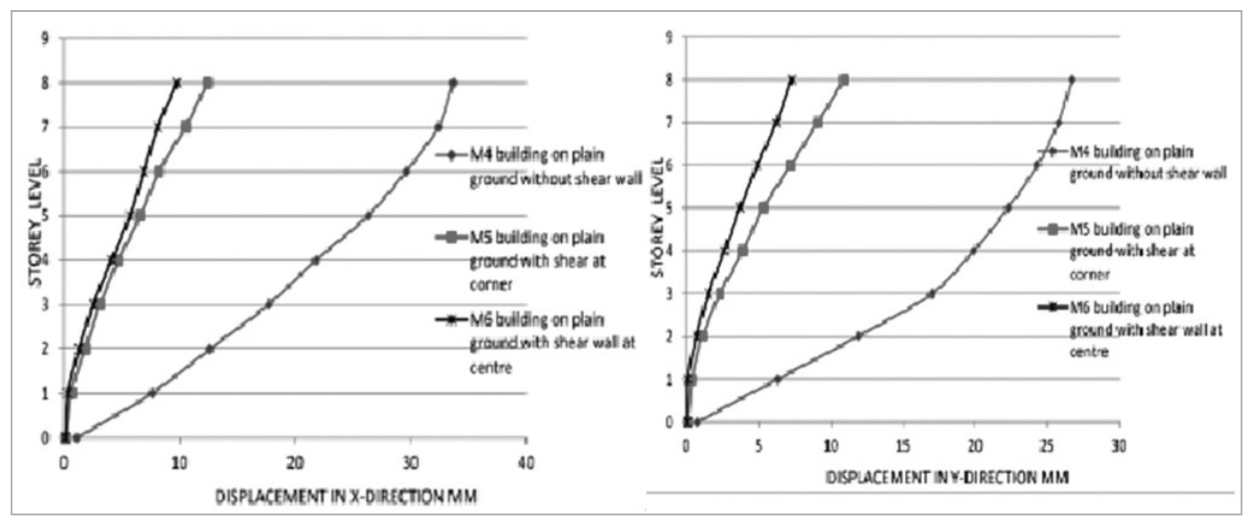

Fig 7: Lateral displacement of M4, M5 and M6 inmm due to response spectrum analysis along $X$ and $Y$ direction

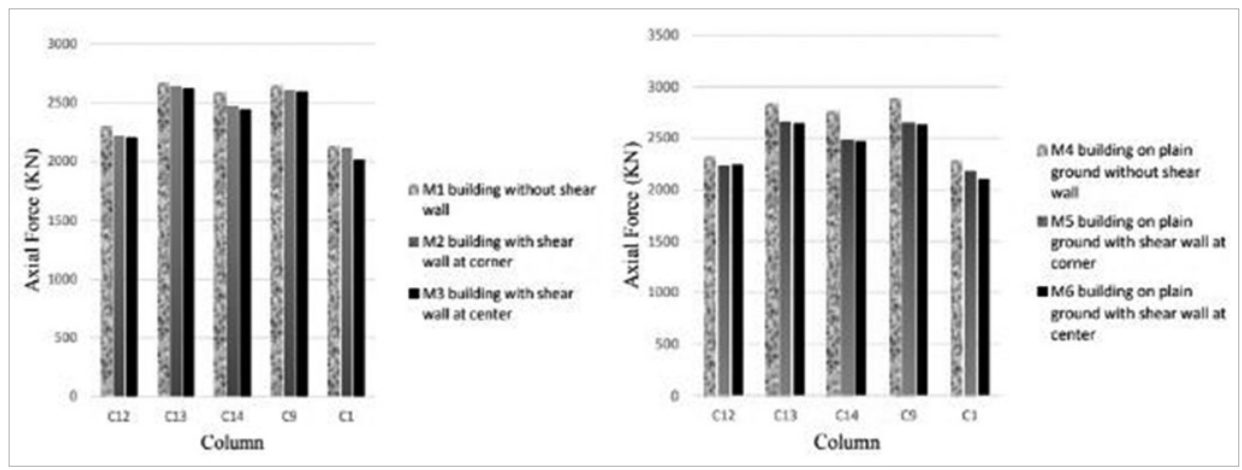

Fig 8: Variation of Axial force on sloping groundand Plain ground 


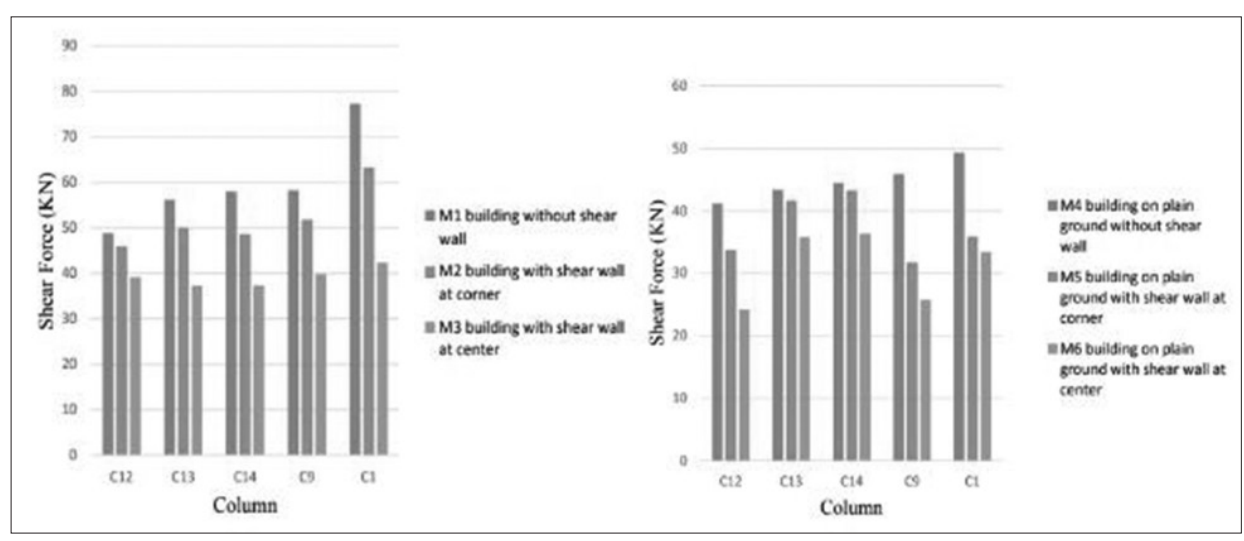

Fig 9: Variation of Shear force on sloping groundand Plain ground

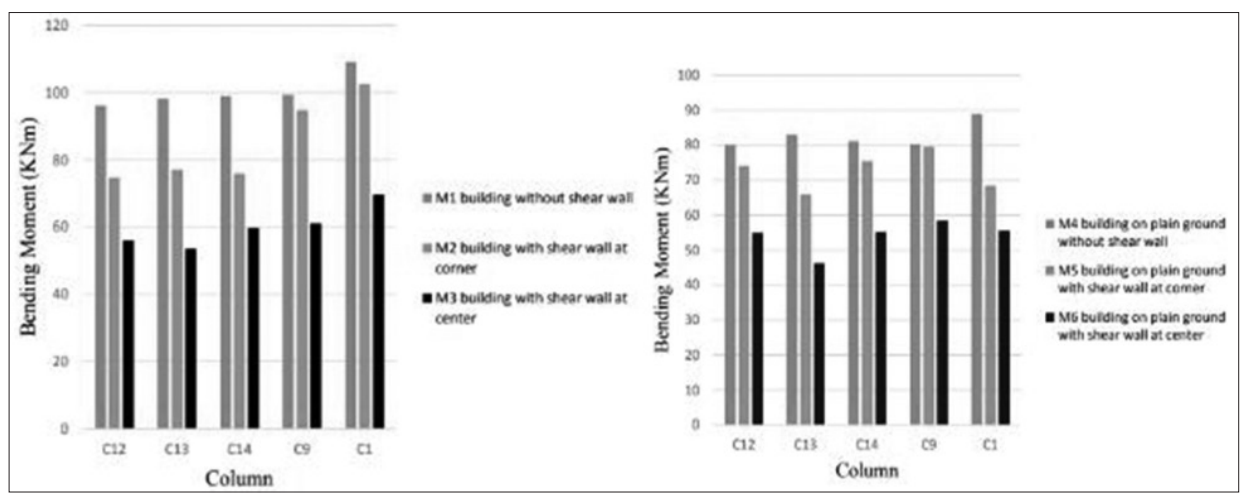

Variation of Bending Moment on slopingground and Plain ground

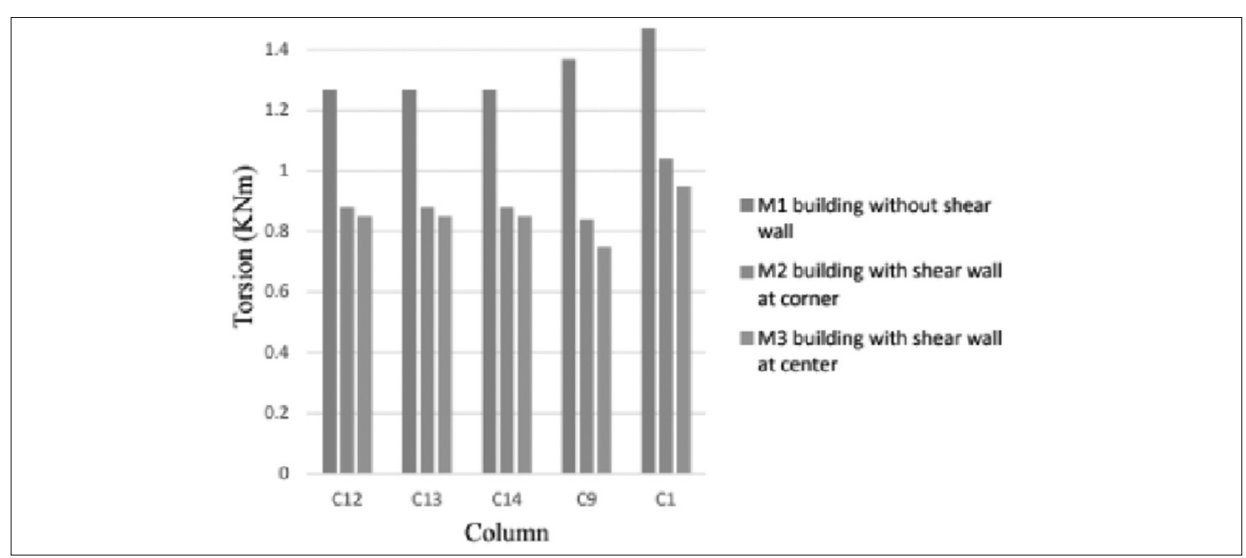

Fig 11: Variation of Torsion on sloping ground 

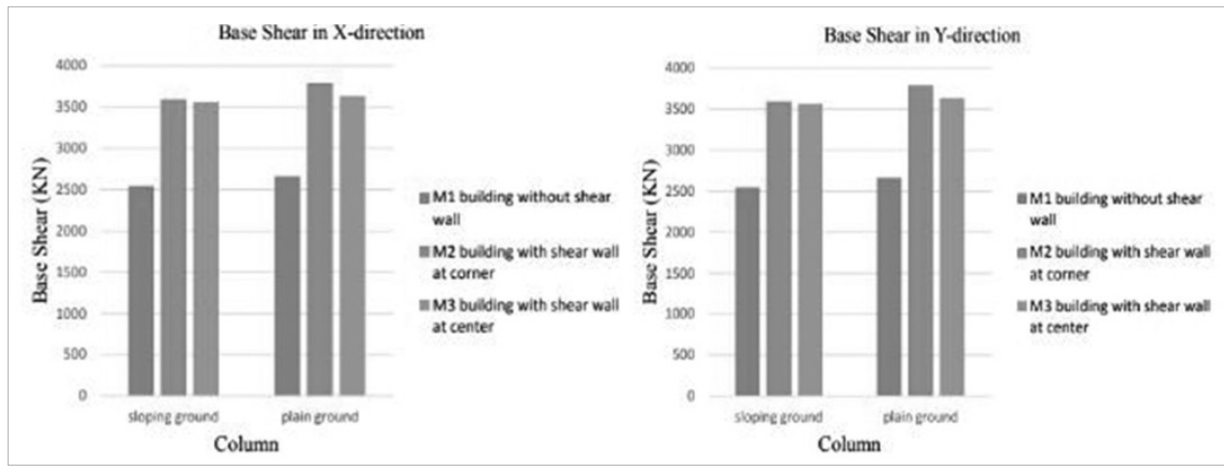

Fig 12: Variation of base shear in $X$ and $Y$ directionon plain and sloping ground

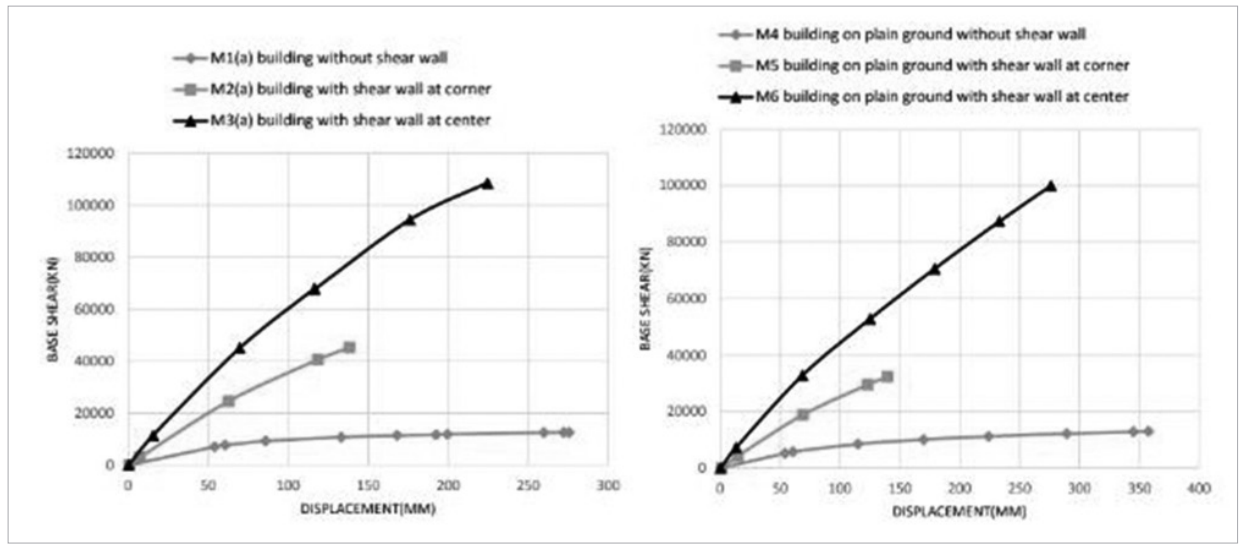

Fig13: Variation of pushover curve for building onsloping ground and Plain ground

\section{Conclusions}

Based on linear static (ESA), Linear dynamic (RSA) and non-linear static (pushover) analysis of building on sloping ground i.e M1, M2, M3 and on plain ground i.e M4, M5, M6 the following conclusions have been drawn:

- $\quad$ Comparing the values of base shear in flat ground and sloped ground building it is maximum for flat ground building.

- Bending moment in columns is higher for buildings on slope compared to that of buildings on plain ground and the presence of shear wall reduces the bending moment in all the cases.

- Shear force in columns is higher for buildings on slope compared to that of buildings on plain ground and the presence of shear wall reduces the Shear force in all the cases.

- $\quad$ Axial force, Shear force and Bending moment is minimum for building with shear wall at center compared to building with shear wall at corner and without shear wall. 
- $\quad$ It is observed that for both sloped ground and plain ground building with shear wall at center the displacement is decreasing compared to building with shear wall at corner. 2

2 Al-Ali, A. A., \& Krawinkler, H. (1999). Effects of vertical irregularities on seismic behavior of building structures. Report No. 130. The John A. Blume Earthquake Engineering Center. Department of Civil and Environmental Engineering Stanford University

2. Birajdar, B. G., \& Nalawade, S. S. (2004, August). Seismic analysis of buildings resting on sloping ground. 13th world conference on earthquake engineering, Vancouver, BC, Canada (Vol. 1, No. 6).

3. Sreerama, A. K., \& Ramancharla, P. K. (2013, October). Earthquake behavior of reinforced concrete framed buildings on hill slopes. International Symposium on New Technologies for Urban Safety of Mega Cities in Asia (USMC-October 2013).

4. Halkude, S. A., Kalyanshetti, M. G., \& Ingle, V. D. (2013). Seismic analysis of buildings resting on sloping ground with varying number of bays and hill slopes. International Journal of Engineering Research \& Technology (IJERT), ISSN, 2278-0181.

5. Doijad, S., \& Bhalchandra, S. (2015). Seismic Behavior of RC Buildings Constructed on Plain and Sloping Ground with Different Configuration of Shear wall. Journal of Civil Engineering and Environmental Technology, 2(10), 59-65.

6. Vaidya, P. R. (2015). Seismic Analysis of Building with Shear Wall on Sloping Ground. International Journal of Civil and Structural Engineering Research, 2(2), 53-60.

7. Swathi, A. S., Rao, G. R., \& Depaa, R. A. B. (2015) Seismic Performance Of Buildings On Sloping Grounds. IJIREST volume 4, special issue 6.

8. Bejgum, S., Udgir, S. S., Wagatti, S. H., \& Harugoppa, R. (2016). Seismic Evaluation with Shear Walls and Braces for Buildings on Sloping Ground. International Journal of Innovative Research in Science, Engineering and Technology. 